\title{
Oestrogen receptor $\beta$ mediates the actions of bisphenol-A on ion channel expression in mouse pancreatic beta cells
}

\author{
Juan Martinez-Pinna ${ }^{1,2,3}$ • Laura Marroqui ${ }^{1,2,4}$ - Abdelkrim Hmadchaa, ${ }^{4,5}$ Javier Lopez-Beas ${ }^{4,5}$ - Sergi Soriano ${ }^{1,2,3}$. \\ Sabrina Villar-Pazos ${ }^{1,2,4}$ • Paloma Alonso-Magdalena ${ }^{1,2,4}$. Reinaldo S. Dos Santos ${ }^{1,2,4}$ • Ivan Quesada ${ }^{1,2,4}$. \\ Franz Martin $^{4,5} \cdot$ Bernat Soria $^{4,5} \cdot$ Jan-Åke Gustafsson ${ }^{6,7} \cdot$ Angel Nadal $^{1,2,4}$
}

Received: 18 February 2019 / Accepted: 26 April 2019 / Published online: 27 June 2019

(C) Springer-Verlag GmbH Germany, part of Springer Nature 2019

\begin{abstract}
Aims/hypothesis Bisphenol-A (BPA) is a widespread endocrine-disrupting chemical that has been associated with type 2 diabetes development. Low doses of BPA modify pancreatic beta cell function and induce insulin resistance; some of these effects are mediated via activation of oestrogen receptors $\alpha(\mathrm{ER} \alpha)$ and $\beta(\mathrm{ER} \beta)$. Here we investigated whether low doses of BPA regulate the expression and function of ion channel subunits involved in beta cell function.

Methods Microarray gene profiling of isolated islets from vehicle- and BPA-treated (100 $\mathrm{\mu g} / \mathrm{kg}$ per day for 4 days) mice was performed using Affymetrix GeneChip Mouse Genome 430.2 Array. Expression level analysis was performed using the normalisation method based on the processing algorithm 'robust multi-array average'. Whole islets or dispersed islets from C57BL/ $6 \mathrm{~J}$ or oestrogen receptor $\beta(\mathrm{ER} \beta)$ knockout $\left(\operatorname{Er} \beta^{-1}\right)$ mice were treated with vehicle or BPA $(1 \mathrm{nmol} / \mathrm{l})$ for $48 \mathrm{~h}$. Whole-cell patchclamp recordings were used to measure $\mathrm{Na}^{+}$and $\mathrm{K}^{+}$currents. mRNA expression was evaluated by quantitative real-time PCR. Results Microarray analysis showed that BPA modulated the expression of 1440 probe sets (1192 upregulated and 248 downregulated genes). Of these, more than 50 genes, including $S c n 9 a, K c n b 2$, Kcnmal and Kcnipl, encoded important $\mathrm{Na}^{+}$and $\mathrm{K}^{+}$ channel subunits. These findings were confirmed by quantitative RT-PCR in islets from C57BL/6J BPA-treated mice or whole islets treated ex vivo. Electrophysiological measurements showed a decrease in both $\mathrm{Na}^{+}$and $\mathrm{K}^{+}$currents in BPA-treated islets. The pharmacological profile indicated that BPA reduced currents mediated by voltage-activated $\mathrm{K}^{+}$channels $\left(\mathrm{K}_{\mathrm{v}} 2.1 / 2.2\right.$ channels) and large-conductance $\mathrm{Ca}^{2+}$-activated $\mathrm{K}^{+}$channels $\left(\mathrm{K}_{\mathrm{Ca}} 1.1\right.$ channels), which agrees with BPA's effects on gene expression. Beta cells from $E R \beta^{-1-}$ mice did not present BPA-induced changes, suggesting that ER $\beta$ mediates BPA's effects in pancreatic islets. Finally, BPA increased burst duration, reduced the amplitude of the action potential and enlarged the action potential halfwidth, leading to alteration in beta cell electrical activity.
\end{abstract}

Juan Martinez-Pinna and Laura Marroqui contributed equally to this work.

Electronic supplementary material The online version of this article (https://doi.org/10.1007/s00125-019-4925-y) contains peer-reviewed but unedited supplementary material, which is available to authorised users.

Angel Nadal

nadal@umh.es

1 Instituto de Biología Molecular y Celular (IBMC), Universitas Miguel Hernández, 03202 Elche, Spain

2 Instituto de Investigación, Desarrollo e Innovación en Biotecnología Sanitaria de Elche (IDiBE), Universitas Miguel Hernández, Elche, Spain

3 Departamento de Fisiología, Genética y Microbiología, Universidad de Alicante, Alicante, Spain
4 Centro de Investigación Biomédica en Red de Diabetes y Enfermedades Metabólicas Asociadas (CIBERDEM), Spain, http://www.ciberdem.org/

5 Department of Cell Regeneration and Advanced Therapies, Andalusian Center for Molecular Biology and Regenerative Medicine-CABIMER, University of Pablo Olavide-University of Seville-CSIC, Seville, Spain

6 Department of Cell Biology and Biochemistry, Center for Nuclear Receptors and Cell Signaling, University of Houston, Houston, TX, USA

Department of Biosciences and Nutrition, Karolinska Institut, Huddinge, Sweden 


\section{Research in context}

What is already known about this subject?

- The widespread endocrine-disrupting chemical bisphenol-A (BPA) may be involved in the aetiology of type 2 diabetes

- Low doses of BPA alter beta cell function and induce insulin resistance in vivo

- Some of BPA's effects on beta cells occur through activation of oestrogen receptors a (ERa) and $\beta$ (ER $\beta$ )

\section{What is the key question?}

- Does BPA treatment modulate the expression and function of ion channels in mouse pancreatic islets?

What are the new findings?

- Microarray analysis showed that BPA modulated the expression of 1440 genes, of which more than 50 encoded important $\mathrm{Na}^{+}$and $\mathrm{K}^{+}$channel subunits; several of these changes were confirmed by real-time PCR

- Electrophysiological measurements showed a decrease in both $\mathrm{Na}^{+}$and $\mathrm{K}^{+}$currents in BPA-treated islets

- $\quad$ BPA-induced changes were absent in beta cells from $\operatorname{Er} \beta$ knockout mice

How might this impact on clinical practice in the foreseeable future?

- Understanding which ion channels are regulated by BPA and how BPA initiates its actions on beta cells might shed some light on the mechanisms whereby BPA and other endocrine-disrupting chemicals may lead to insulin resistance and type 2 diabetes

Conclusions/interpretation Our data suggest that BPA modulates the expression and function of $\mathrm{Na}^{+}$and $\mathrm{K}^{+}$channels via ER $\beta$ in mouse pancreatic islets. Furthermore, BPA alters beta cell electrical activity. Altogether, these BPA-induced changes in beta cells might play a role in the diabetogenic action of BPA described in animal models.

Keywords Beta cell $\cdot$ Bisphenol-A $\cdot$ Diabetes $\cdot$ Endocrine-disrupting chemicals $\cdot \mathrm{K}^{+}$channels $\cdot \mathrm{Na}^{+}$channels $\cdot$ Oestrogen receptor $\beta$

$\begin{array}{ll}\text { Abbreviations } & \\ \text { BPA } & \text { Bisphenol-A } \\ \mathrm{Ca}_{\mathrm{v}} & \text { Voltage-activated } \mathrm{Ca}^{+} \text {channel } \\ \text { DAVID } & \begin{array}{l}\text { Database for Annotation, Visualization and } \\ \text { Integrated Discovery }\end{array} \\ \text { DEG } & \text { Differentially expressed gene } \\ \text { DPN } & \text { Diarylpropionitrile } \\ \text { EDC } & \text { Endocrine-disrupting chemical } \\ \text { ER } \alpha & \text { Oestrogen receptor } \alpha \\ \text { ER } \beta & \text { Oestrogen receptor } \beta \\ \text { GO } & \text { Gene ontology } \\ \text { GSIS } & \text { Glucose-stimulated insulin secretion } \\ \text { IbTx } & \text { Iberiotoxin } \\ \mathrm{K}_{\mathrm{ATP}} \text { channel } & \text { ATP-sensitive } \mathrm{K}^{+} \text {channel } \\ \mathrm{K}_{\mathrm{Ca}} 1.1 \text { channel } & \text { Large-conductance } \mathrm{Ca}^{2+} \text {-activated } \\ & \mathrm{K}^{+} \text {channel } \\ \mathrm{K}_{\mathrm{Ca}} 2.3 \text { channel } & \text { Small-conductance } \mathrm{Ca}^{2+} \text {-activated } \\ \mathrm{KEGG}^{+} \text {channel } & \mathrm{K}^{2} \\ & \text { Geto Enomes }\end{array}$

$\begin{array}{ll}\mathrm{K}_{\mathrm{V}} \text { channel } & \text { Voltage-activated } \mathrm{K}^{+} \text {channel } \\ \mathrm{Na}_{\mathrm{v}} \text { channel } & \text { Voltage-activated } \mathrm{Na}^{+} \text {channel } \\ \text { qRT-PCR } & \text { Quantitative RT-PCR } \\ \text { ScTx } 1 & \text { Stromatoxin- } 1\end{array}$

\section{Introduction}

Pancreatic beta cells play a major role in glucose homeostasis because they biosynthesise and release insulin, a key hormone in blood glucose regulation. Decreased insulin release in response to glucose results in chronic hyperglycaemia, a hallmark of type 2 diabetes, a metabolic disease that affects over 400 million people around the world [1].

Glucose-stimulated insulin secretion (GSIS) from pancreatic beta cells is controlled by electrical activity. In the absence of stimulatory glucose concentrations, beta cells maintain a hyperpolarised membrane potential due to the high activity of the ATP-sensitive $\mathrm{K}^{+}$channel ( $\mathrm{K}_{\mathrm{ATP}}$ channel). Upon 
glucose stimulation, $\mathrm{K}_{\mathrm{ATP}}$ channel activity decreases due to the rise in the ATP : ADP ratio. This reduction in activity increases membrane input resistance and, consequently, small depolarising currents produce important changes in the membrane potential, generating an oscillatory (bursting) electrical activity that alternates between a hyperpolarised silent phase and a depolarised phase with action potentials [2-4]. This bursting pattern of electrical activity induces an oscillatory pattern of intracellular $\mathrm{Ca}^{2+}$ concentration [5] and exocytosis of insulin-containing vesicles [6]. In mouse beta cells, the depolarisation phase of the action potential depends on the activation of voltage-activated $\mathrm{Ca}^{2+}$ channels, while the repolarisation phase depends on currents generated by delayed rectifying voltage-activated $\mathrm{K}^{+}$channels $\left(\mathrm{K}_{\mathrm{v}}\right.$ channels) $\mathrm{K}_{\mathrm{v}} 2.1$ / 2.2 [7-9] and large-conductance $\mathrm{Ca}^{2+}$-activated $\mathrm{K}^{+}$channels $\left(\mathrm{K}_{\mathrm{Ca}} 1.1\right.$ channels) [10]. Mouse beta cells express the voltageactivated $\mathrm{Na}^{+}$channels $\left(\mathrm{Na}_{\mathrm{v}}\right.$ channels) $\mathrm{Na}_{\mathrm{v}} 1.3$ and $\mathrm{Na}_{\mathrm{v}} 1.7$. $\mathrm{Na}_{\mathrm{v}} 1.3$ participates in the depolarisation of the action potential and affects insulin secretion [11]; $\mathrm{Na}_{\mathrm{v}} 1.7$ does not participate in insulin release, yet it might play a role in insulin production [12] and beta cell survival [13]. The repolarisation phase between bursts of action potential is due to small-conductance $\mathrm{Ca}^{2+}$-activated $\mathrm{K}^{+}$channels $\left(\mathrm{K}_{\mathrm{Ca}} 2.3\right.$ channels) $[6,14,15]$.

Type 2 diabetes results from gene-environment interactions over time. Genetic alterations in the expression of voltage-activated channels have important consequences for beta cell function and the development of type 2 diabetes [ 6 , 14]. Additionally, animal studies have shown that exposure to bisphenol-A (BPA) alters beta cell function and induces insulin resistance [16-19]. BPA is found in the urine of $93 \%$ of USA citizens [20] and its concentrations in human serum varies between 1 and $25 \mathrm{nmol} / \mathrm{l}$, depending on sex, age and geographical regions, among other factors [21]. BPA has been added by the European Chemical Agency (ECHA) to the candidate list of substances of very high concern due to its endocrine-disrupting properties [22]. In beta cells, low concentrations of BPA (e.g. $1 \mathrm{nmol} / \mathrm{l}$, in vitro) trigger extranuclearinitiated actions via oestrogen receptors $\alpha(E R \alpha)$ and $\beta(E R \beta)$. Within a few minutes, BPA blocks $\mathrm{K}_{\text {ATP }}$ channels via $\mathrm{ER} \beta$ and potentiates GSIS [19]. Longer in vitro BPA treatments (up to $48 \mathrm{~h}$ ) upregulate insulin mRNA expression and increase insulin content as well as GSIS in an ER $\alpha$-dependent manner [17]. Recent work demonstrated that BPA treatment for $48 \mathrm{~h}$ downregulated the voltage-activated $\mathrm{Ca}^{2+}$ channel $\mathrm{Ca}_{\mathrm{v}} 2.3$ in an ER $\beta$-dependent manner, leading to decreased amplitude of action potential and diminished exocytosis in the absence of stimulatory glucose levels. Surprisingly, GSIS was still enhanced by BPA treatment [23].

Here, we investigated whether BPA modulated the expression and activity of ion channel subunits in pancreatic islets. This study may help us to understand the regulation of GSIS by this common endocrine-disrupting chemical (EDC).

\section{Methods}

Chemical substances and animals The chemical substances used herein are described in the electronic supplementary material (ESM) Methods. Adult male mice, OF1 (11 weeks old; Charles River, Barcelona, Spain) for in vivo treatment (shown in Fig. 1) and C57BL/6J (10-14 weeks old; Envigo, Barcelona, Spain) for the rest of the experiments, were kept under standard housing conditions (12 h light-dark cycle, food ad libitum) in polypropylene veterinary cages. Mice with knockout of the $\operatorname{Er} \beta$ gene (also known as $E s r 2)\left(E r \beta^{-1-}\right.$ mice), supplied by Jan-Åke Gustafsson's laboratory, were generated as previously described [24]. Wild-type littermates and $\operatorname{Er} \beta^{-/-}$ mice were obtained from the same supplier and colony. Animals were randomly assigned before BPA treatment. Experimental procedures were carried out according to the Spanish Royal Decree 1201/2005 and the European Community Council directive 2010/63/EU. All methods used herein were approved by the Ethics Committee from Universidad Miguel Hernández de Elche (Alicante, Spain) (protocols ID: UMH-IB-AN-01-14 and UMH-IB-AN-02-14).

BPA treatment For in vivo experiments (three to seven mice per condition), BPA was dissolved in tocopherol-stripped corn oil; a total of $100 \mu \mathrm{g} / \mathrm{kg}$ per day (two injections of $50 \mu \mathrm{g} / \mathrm{kg}$ per day) was administered subcutaneously for 4 days. The same volume of tocopherol-stripped corn oil $(100 \mu \mathrm{l})$ was used as vehicle. Sixteen hours after the last injection, mice were killed and islets were isolated. For ex vivo experiments, BPA was prepared each week by dissolution in DMSO (used as vehicle).

Culture of islets and dispersed islet cells Pancreatic islets were isolated using collagenase (Sigma, St Louis, MO, USA) as described [25]. For some experiments, pancreatic islets were dispersed into isolated cells [26]. Before any treatment, whole islets and dispersed cells were cultured for $48 \mathrm{~h}$ at $37^{\circ} \mathrm{C}$ in a humidified atmosphere of $95 \% \mathrm{O}_{2}$ and $5 \% \mathrm{CO}_{2}$. See ESM Methods for further details.

Microarray analysis Islets from three BPA-treated OF1 male mice were isolated. Total RNA was isolated using the RNeasy Mini Kit (Qiagen, Venlo, the Netherlands) and $1 \mu \mathrm{g}$ was used to obtain the gene expression profile of each sample. Biotinylated cRNA $(10 \mu \mathrm{g})$ prepared from total RNA was hybridised on an Affymetrix GeneChip Mouse Genome 430 2.0 Array (Affymetrix, Santa Clara, CA, USA). Microarrays were scanned using GeneChip Scanner 3000 7G (Affymetrix, Santa Clara, CA, USA) and were processed with GeneChip Operating System (GCOS) 1.4.0.036 (Affymetrix) to generate the CEL file expression data. All analyses were conducted according to the manufacturer's instructions. Statistical data analyses were performed using the Limma package (affylmGUI interface) of the 
a

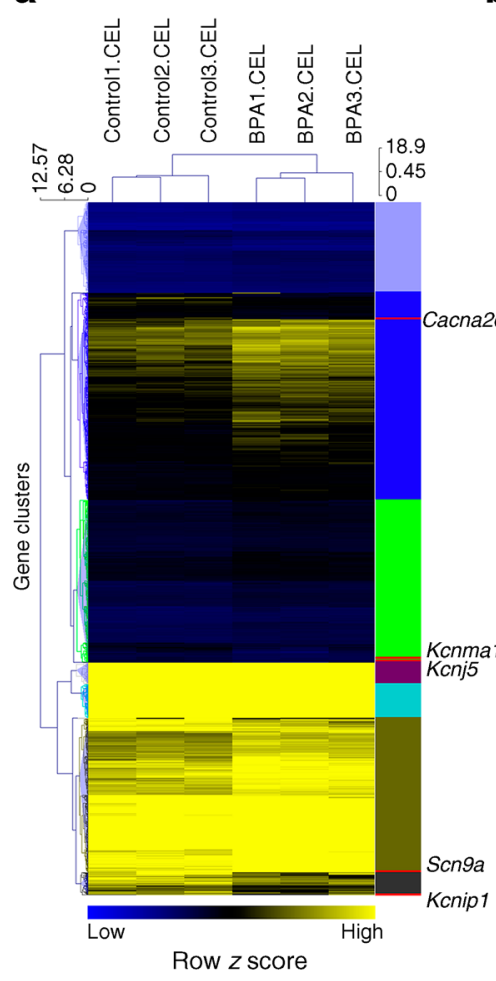

b
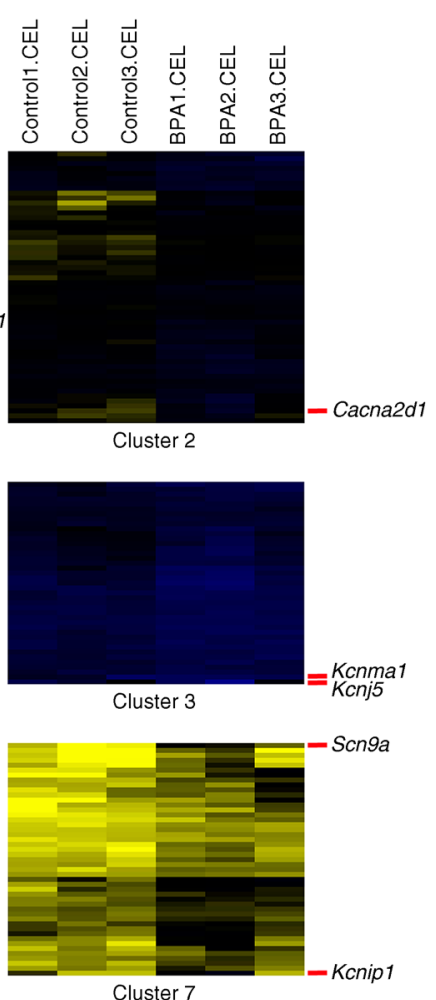

C

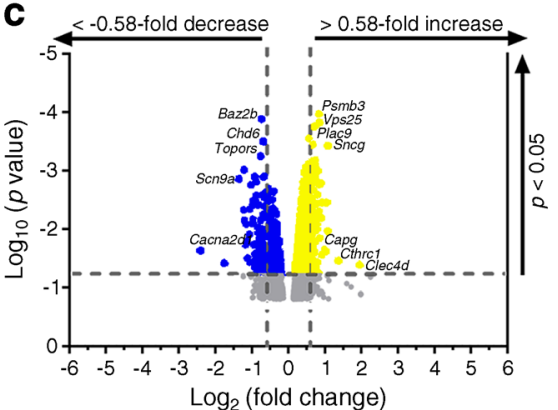

d

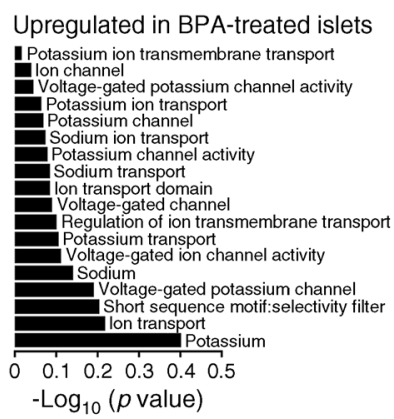

Downregulated in BPA-treated islets

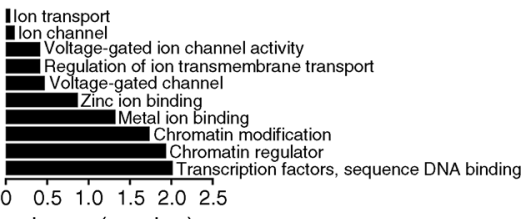

- $\log _{10}(p$ value)
Fig. 1 Microarray analysis of islets from mice treated with vehicle (control) or BPA $100 \mu \mathrm{g} / \mathrm{kg}$ per day for 4 days. (a) Dendrogram and hierarchical clustering heat map of gene subsets with similar expression patterns using the open-source data analysis Multiple Experiment Viewer $(\mathrm{MeV})$ software package, between control and BPA-treated islets (3 replicates each). Genes are grouped together and are connected by a series of branches (clustering tree or dendrogram) according to the average linkage method (cluster-to-cluster distance is defined as the average distance between all members of one cluster and all members of another cluster) using the Euclidean distance (distance threshold $=3.26$ ) as a measure of similarity. The rows in the heat map represent cluster genes and their measurements, while columns represent different experimental conditions; the scales were assessed by the unweighted pair group method with arithmetic mean (UPGMA) algorithm, which associates the similarity between the samples (top right scale: $0,0.45$ and 18.9) and the genes (top left scale: $0,6.28$ and 12.57). The coloured support boxes to the right highlight clusters (1 to 7). The scaled expression value, denoted as the row $z$-score, is plotted in yellow-blue colour scale with blue indicating

R Bioconductor project (http://www.bioconductor.org; R package version 2.7.0). Genes were considered significantly upregulated or downregulated when their expression values were fold change (linear) $>1.5$ and $p$ value $<0.05$. Functional annotation and biological term enrichment were performed using Database for Annotation, Visualization and Integrated Discovery (DAVID 6.8; https://david.ncifcrf.gov). Enrichment of Gene Ontology (GO; http://www.geneontology.org) Biological Process terms were considered as statistically significant when $p<0.05$ (Genomic core facility of CABIMER) [27, 28]. decreased expression (low), black indicating unchanged expression and yellow indicating increased expression (high). Expression data are shown for genes with $\log _{2}$ (fold change) differences of expression $>0.58$ $(p<0.05)$. (b) Expanded view of hierarchical clustering heat maps for pancreatic genes of interest detected within clusters 2 (blue box), 3 (green box) and 7 (black box), showing the expression signatures of gene candidates in PBA-treated mice, as determined by applying $k$ means clustering algorithms ( $k=10$; maximum iterations 50). (c) Scatter plot with $\log _{2}$ fold change of DEGs between control and BPA-treated islets $(p<0.05)$. Selected upregulated and downregulated genes in islets are highlighted in blue (indicating decreased expression) and in yellow (indicating increased expression) ( $n=3$ mice per group). (d) The predicted Biological Process GO terms identified to be upregulated ( $n=18$ terms) or downregulated ( $n=10$ terms) in BPA-treated islets. The $p$ value was used to determine the significance of enrichment or overrepresentation of terms for each annotation. The ranking score was obtained using enrichment $-\log _{10}(p$ value) from the predicted target genes. The $x$-axis represents score and the $y$-axis represents the top enriched signalling pathways

Dendrograms and hierarchical clustering heat maps were generated using the open-source data analysis Multiple Experiment Viewer (MeV) software package version 4.0, available at: http://mev.tm4.org/.

$\mathrm{Na}^{+}$and $\mathrm{K}^{+}$currents In Figs 2 and 4 and ESM Figs 2, 4 and 5, the whole-cell patch-clamp configuration was used, while in Fig. 5 and ESM Fig. 1 we used the perforated patch whole-cell recording mode. Data were acquired using an Axopatch 200B patch-clamp amplifier (Axon Instruments, San Jose, CA, 

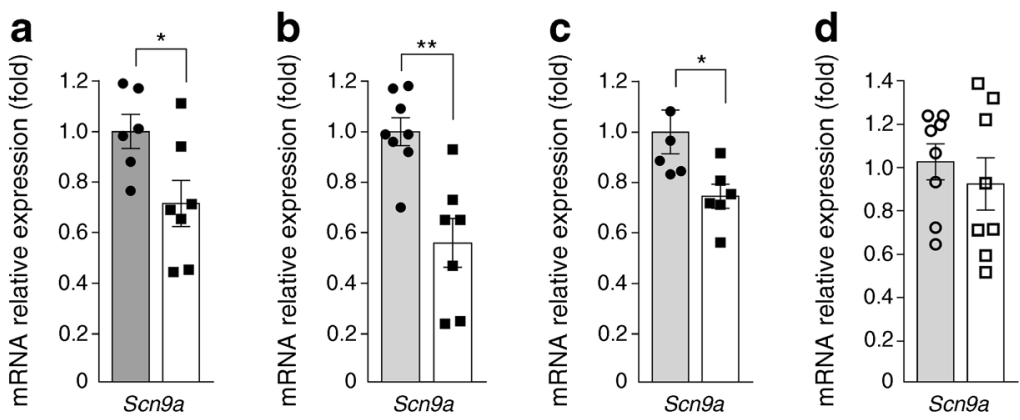

e
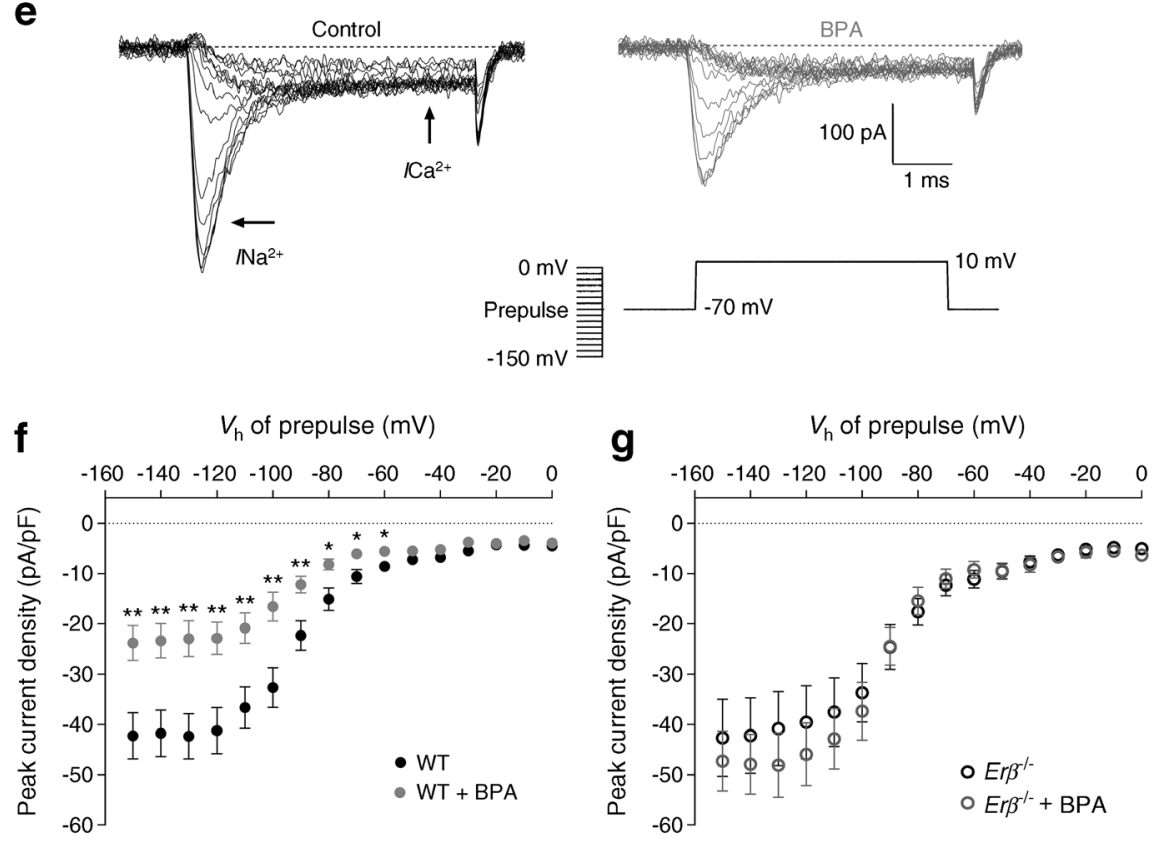

Fig. 2 BPA inhibits $\mathrm{Na}^{+}$currents in mouse pancreatic beta cells. (a) mRNA expression of $S c n 9 a$ in islets from mice treated with vehicle (control; grey bars) or BPA $100 \mu \mathrm{g} / \mathrm{kg}$ per day (white bars) for four days. (b) Scn 9 a mRNA expression in islets treated ex vivo with vehicle (control; light grey bars) or BPA $1 \mathrm{nmol} / \mathrm{l}$ (white bars) for $48 \mathrm{~h}$. (c, d) $S c n 9 a$ mRNA expression in islets from wild-type (c) and $\operatorname{Er}^{-/-}$(d) mice treated ex vivo with vehicle (control; light grey bars) or BPA $1 \mathrm{nmol} / \mathrm{l}$ (white bars) for $48 \mathrm{~h}$. mRNA expression in (a-d) was measured by qRT-PCR and normalised to the housekeeping gene Hprt1 and is shown as fold vs control. Data are shown as means \pm SEM of: six or seven (a), seven or eight (b), five or six (c) or eight (d) independent experiments: $* p \leq 0.05, * * p \leq 0.01$ (Student's $t$ test). (e) Representative recordings of $\mathrm{Na}^{+}$and $\mathrm{Ca}^{2+}$ currents in response to a depolarising voltage pulse $(-70 \mathrm{mV}$ to $+10 \mathrm{mV} ; 5 \mathrm{~ms}$

USA). All experiments were performed at $32-34^{\circ} \mathrm{C}$. See Ref. [23] and ESM Methods for further details.

Real-time PCR Quantitative RT-PCR (qRT-PCR) was performed using the CFX96 Real-Time System (Bio-Rad Laboratories, Hercules, CA, USA). RNA was extracted using RNeasy Micro kit (Qiagen) and reverse-transcribed using the High-Capacity cDNA Reverse Transcription kit (Applied Biosystems, Foster City, CA, USA). Amplification reactions were performed as described [23]. Values were analysed with CFX Manager Version 1.6 (Bio-Rad) and expressed as the duration) after conditioning prepulses (from $-150 \mathrm{mV}$ to $0 \mathrm{mV}$ ) (inset) in dispersed cells treated with vehicle (control) or BPA $1 \mathrm{nmol} / 1$ for $48 \mathrm{~h}$ $\mathrm{Na}^{+}$currents are clearly distinguishable from $\mathrm{Ca}^{2+}$ currents by their faster activation and inactivation kinetics (indicated by arrows). (f, g) Relationship between $\mathrm{Na}^{+}$current density $\left(\mathrm{Na}^{+}\right.$currents in $\mathrm{pA}$ normalised to the cell capacitance in $\mathrm{pF}$ ) and the voltage of the prepulses in dispersed cells from wild-type (WT) (f) and $\operatorname{Er} \beta^{-1-}$ (g) mice treated ex vivo with vehicle (control, $n=9$ beta cells) or BPA $1 \mathrm{nmol} / 1$ ( $n=12$ beta cells) for $48 \mathrm{~h}$. Data are shown as means \pm SEM of the number of cells recorded. These cells were isolated from five (f) or three $(\mathbf{g})$ mice on at least three different days: $* p \leq 0.05, * * p \leq 0.01$ vs control at the same $V_{\mathrm{h}}$ (Student's $t$ test). $V_{\mathrm{h}}$, holding potential

relative expression in respect of control values $\left(2^{-\Delta \Delta \mathrm{C}_{\mathrm{t}}}\right)$ [29]. Hprt was used as housekeeping gene. Similar results were obtained when Gapdh was used as housekeeping gene (data not shown). The primers used herein are listed in ESM Table 1.

Statistical analysis Experimenters were not blind to group assignment and outcome assessment. GraphPad Prism 5.0 software (GraphPad Software, La Jolla, CA, USA) was used for most statistical analyses. Data are expressed as the mean \pm SEM. To assess differences between groups, we used two- 
tailed Student's $t$ test or ANOVA when appropriate. For nonparametric data we used Mann-Whitney and Kruskal-Wallis ANOVA tests (followed by Dunn's test), depending on the experimental groups involved in the comparison. Except for the microarray analysis (see above), a $p$ value $\leq 0.05$ was considered statistically significant.

\section{Results}

$B P A$ regulates ion channel subunits expression in mouse islets To study the effects of BPA on beta cell gene expression, we treated adult OF1 male mice with vehicle (control; $n=3$ ) or BPA $100 \mu \mathrm{g} / \mathrm{kg}$ per day $(n=3)$ for 4 days. Afterwards, we performed a microarray analysis of islets obtained from both groups. Hierarchical clustering analysis of differentially expressed genes showed a clear separation between control and BPA-treated islets (Fig. 1a). In vivo BPA treatment significantly modified the expression of 1440 probe sets, of which 1192 were upregulated and 248 downregulated. Overall, our analysis identified 50 genes related to ion channel subunits within clusters 2, 3 and 7, including Cacn $2 d 1$, Kcnmal and Scn9a (Fig. 1b,c and Table 1). Based on these observations, we performed a DAVID analysis to identify potentially enriched biological processes among the putative target genes of the differentially expressed genes (DEGs) using GO terms (http://www.geneontology.org), and to identify the related pathways using the Kyoto Encyclopedia of Genes and Genomes (KEGG) pathway database (https://www.genome. jp/kegg; Release 89.0, January 1, 2019). Gene ontology enrichment analysis revealed several DEGs related to ion channel subunit regulation (Fig. 1c). Besides, based on these DEGs, 18 upregulated and ten downregulated signalling pathways were identified in BPA-treated islets predicted to be mainly related to ion channels (Fig. 1d).

\section{BPA reduces the expression of $\mathrm{Na}^{+}$channel subunits and $\mathrm{Na}^{+}$} currents via ER $\beta$ The $\mathrm{Na}_{\mathrm{v}} 1.7$ channel is the most abundant $\mathrm{Na}^{+}$ channel in mouse beta cells, contributing to approximately $85 \%$ of the $\mathrm{Na}^{+}$current [30]. Our microarray analysis indicated that expression of the $\mathrm{Na}_{\mathrm{v}} 1.7$ channel, encoded by $\operatorname{Scn} 9 a$, was downregulated upon BPA exposure (Fig. 1, Table 1). To confirm these data, we measured $\operatorname{Scn} 9 a$ expression in islets from C57BL/6J BPA-treated mice $(100 \mu \mathrm{g} / \mathrm{kg}$ per day for 4 days) or mouse islets treated ex vivo (BPA $1 \mathrm{nmol} / 1$ for $48 \mathrm{~h}$ ). We observed that BPA treatment diminished Scn9a expression in mouse islets in vivo and ex vivo (Fig. 2a,b). To assess whether this downregulation affected $\mathrm{Na}^{+}$currents in beta cells, we recorded the currents using perforated patchclamp whole-cell recordings in response to a depolarising pulse from $-70 \mathrm{mV}$ to $10 \mathrm{mV}$, preceded by a prepulse from $-150 \mathrm{mV}$ to $0 \mathrm{mV}$ to remove inactivation of $\mathrm{Na}_{\mathrm{v}} 1.7$ channel currents [11] (ESM Fig. 1). As expected, BPA treatment significantly reduced voltage-activated $\mathrm{Na}^{+}$currents, possibly due to $\operatorname{Scn} 9 a$ downregulation. Of note, expression of $S c n 3 a$, which encodes the $\mathrm{Na}_{\mathrm{v}} 1.3$ channel, was not modified by BPA treatment (Table 1). As a positive control of the oestrogenic effects of BPA, we measured $\mathrm{Na}^{+}$currents in control and $17 \beta$ oestradiol-treated beta cells. The $17 \beta$-oestradiol-treated beta cells presented reduced voltage-activated $\mathrm{Na}^{+}$currents when compared with control beta cells (ESM Fig. 2a,b).

Our recent findings suggest that, in pancreatic islets, BPA $1 \mathrm{nmol} / 1$ downregulates the voltage-activated $\mathrm{Ca}^{2+}$ channel $\mathrm{Ca}_{\mathrm{v}} 2.3$ and decreases the R-type $\mathrm{Ca}^{2+}$ current in an ER $\beta$ dependent manner [23]. To evaluate whether ER $\beta$ played a role in the regulation of $\mathrm{Na}^{+}$currents upon BPA exposure, we treated islets from wild-type and $\operatorname{Er} \beta^{-/-}$mice with BPA $1 \mathrm{nmol} / \mathrm{l}$ for $48 \mathrm{~h}$. While BPA decreased $\operatorname{Scn} 9 a$ expression (Fig. 2c) and $\mathrm{Na}^{+}$currents (Fig. 2e,f) in wild-type mouse islets, its effects on $\mathrm{Scn} 9 a$ expression (Fig. 2d) and $\mathrm{Na}^{+}$currents (Fig. 2g) were abolished in islets from $\operatorname{Er} \beta^{-1-}$ mice. Moreover, treatment with the ER $\beta$ agonist diarylpropionitrile (DPN, $1 \mathrm{nmol} / \mathrm{l}$ ) decreased $\mathrm{Na}^{+}$currents (ESM Fig. 2c), which supports a role for $\mathrm{ER} \beta$ in the modulation of $\mathrm{Na}^{+}$currents.

BPA modulates the expression of different $\mathrm{K}^{+}$channel subunits As demonstrated by our microarray analysis, BPA modulated the expression of several genes related to $\mathrm{K}^{+}$channels (see Table 1). To confirm these changes, we measured Kcnab2, Kcnc4 and Kcnj12 mRNA expression in islets from BPA-treated mice $(100 \mu \mathrm{g} / \mathrm{kg}$ per day for 4 days $)$ or mouse islets treated ex vivo (BPA $1 \mathrm{nmol} / 1$ for $48 \mathrm{~h}$ ) (ESM Fig. 3). As observed in the microarray analysis, Kcnab2 and Kcnc4 expression was increased (ESM Fig. 2a,b,d,e), while Kcnj12 was downregulated by BPA treatment (ESM Fig. 3c,f).

BPA reduces the expression of $\mathrm{K}^{+}$channel subunits and $\mathrm{K}^{+}$ currents via ER $\beta$ The voltage-activated $\mathrm{K}^{+}$channels $\mathrm{K}_{\mathrm{v}} 2.1$ (encoded by Kcnb1) and $\mathrm{K}_{\mathrm{v}} 2.2$ (Kcnb2), as well as the $\mathrm{K}_{\mathrm{Ca}} 1.1$ channel (Kcnma1), are major contributors of the repolarisation phase of the action potential in beta cells [10, 15, 31]. Furthermore, $\mathrm{K}^{+}$channel-interacting protein 1 (encoded by Kcnip) seems to be important for GSIS [32]. We assessed whether BPA treatment modulated the expression of these channel subunits and observed that, except for Kcnb1, mRNA expression of Kcnb2, Kcnmal and Kcnipl was decreased by BPA treatment in vivo (Fig. 3a-d) and ex vivo (Fig. 3e-h). BPA's effects on Kcnb2, Kcnip1 and Kcnmal mRNA expression was abrogated in islets from $E r \beta^{-1-}$ mice (Fig. 3m-p) when compared with wild-type littermate control mice (Fig. 3i-1).

To determine whether BPA-induced downregulation of these $\mathrm{K}^{+}$channels would be reflected in the $\mathrm{K}^{+}$efflux, we recorded $\mathrm{K}^{+}$currents in beta cells from wild-type and $\operatorname{Er} \beta^{-1-}$ mice using the patch-clamp technique in the whole-cell configuration. Figure $4 \mathrm{a}$ shows the recordings of the $\mathrm{K}^{+}$currents 
Fig. 3 BPA inhibits expression of $\mathrm{K}^{+}$channel subunits in mouse pancreatic beta cells. (a-d) mRNA expression of $K c n b 1$ (a), Kcnb2 (b), Kcnmal (c) and Kcnip1 (d) in islets from mice treated with vehicle (control; grey bars) or BPA $100 \mu \mathrm{g} / \mathrm{kg}$ per day (white bars) for 4 days. (e-h) mRNA expression of $\mathrm{Kcnbl}$ (e), Kcnb2 (f), Kcnmal (g) and Kcnipl (h) in whole mouse islets treated ex vivo with vehicle (control; light grey bars) or BPA $1 \mathrm{nmol} / \mathrm{l}$ (white bars) for $48 \mathrm{~h}$. (ip) mRNA expression of $K c n b 1$ (i, $\mathbf{m}), \operatorname{Kcnb2}(\mathbf{j}, \mathbf{n})$, Kcnmal (k, o) and Kcnipl $(\mathbf{l}, \mathbf{p})$ in islets from wild-type (i-l) and $\operatorname{Er} \beta^{-/-}(\mathbf{m}-\mathbf{p})$ mice treated ex vivo with vehicle (control; light grey bars) or BPA $1 \mathrm{nmol} / \mathrm{l}$ (white bars) for $48 \mathrm{~h}$. mRNA expression was measured by qRT-PCR and normalised to the housekeeping gene Hprt 1 and is shown as fold vs control. Data are shown as means $\pm \mathrm{SEM}$ of: six to seven (a-d), nine (e-h), four to six (i-I) or eight (m-p) independent experiments: ${ }^{*} p \leq 0.05, * * p \leq 0.01, * * * p \leq 0.001$ (Student's $t$ test)
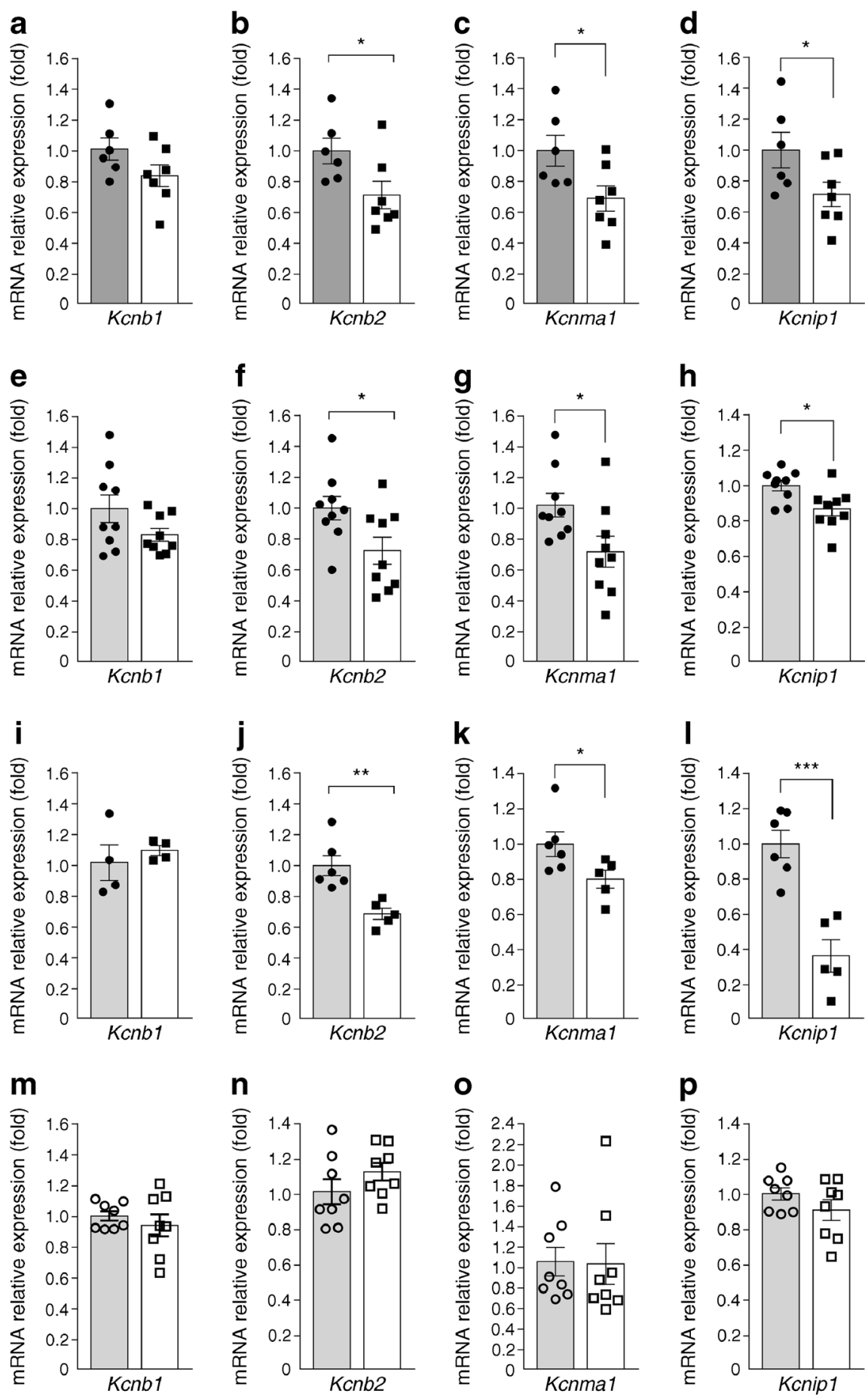

in response to depolarising voltage pulses from $-60 \mathrm{mV}$ to $+80 \mathrm{mV}$ from a holding potential of $-70 \mathrm{mV}$ in cells from wild-type mice. When compared with vehicle-treated cells, currents were significantly smaller in BPA-treated cells starting from $0 \mathrm{mV}$, which is about the peak of glucoseinduced action potentials (Fig. 4b). Measurements of the whole-cell $\mathrm{K}^{+}$currents showed that BPA had no effect on peak current density in beta cells from $\operatorname{Er} \beta^{-/}$mice (Fig. 4c). We further assessed whether ER $\beta$ was indeed involved in the regulation of $\mathrm{K}^{+}$currents by measuring $\mathrm{K}^{+}$currents in control and DPN-treated cells. We observed that DPN treatment decreased $\mathrm{K}^{+}$currents, supporting a role for ER $\beta$ in the modulation of $\mathrm{K}^{+}$currents (ESM Fig. 4).

$\mathrm{K}^{+}$currents result from the passage of $\mathrm{K}^{+}$through several types of voltage- and $\mathrm{Ca}^{2+}$-activated $\mathrm{K}^{+}$channels whose expression was changed by BPA exposure (Figs 1 and 3, 

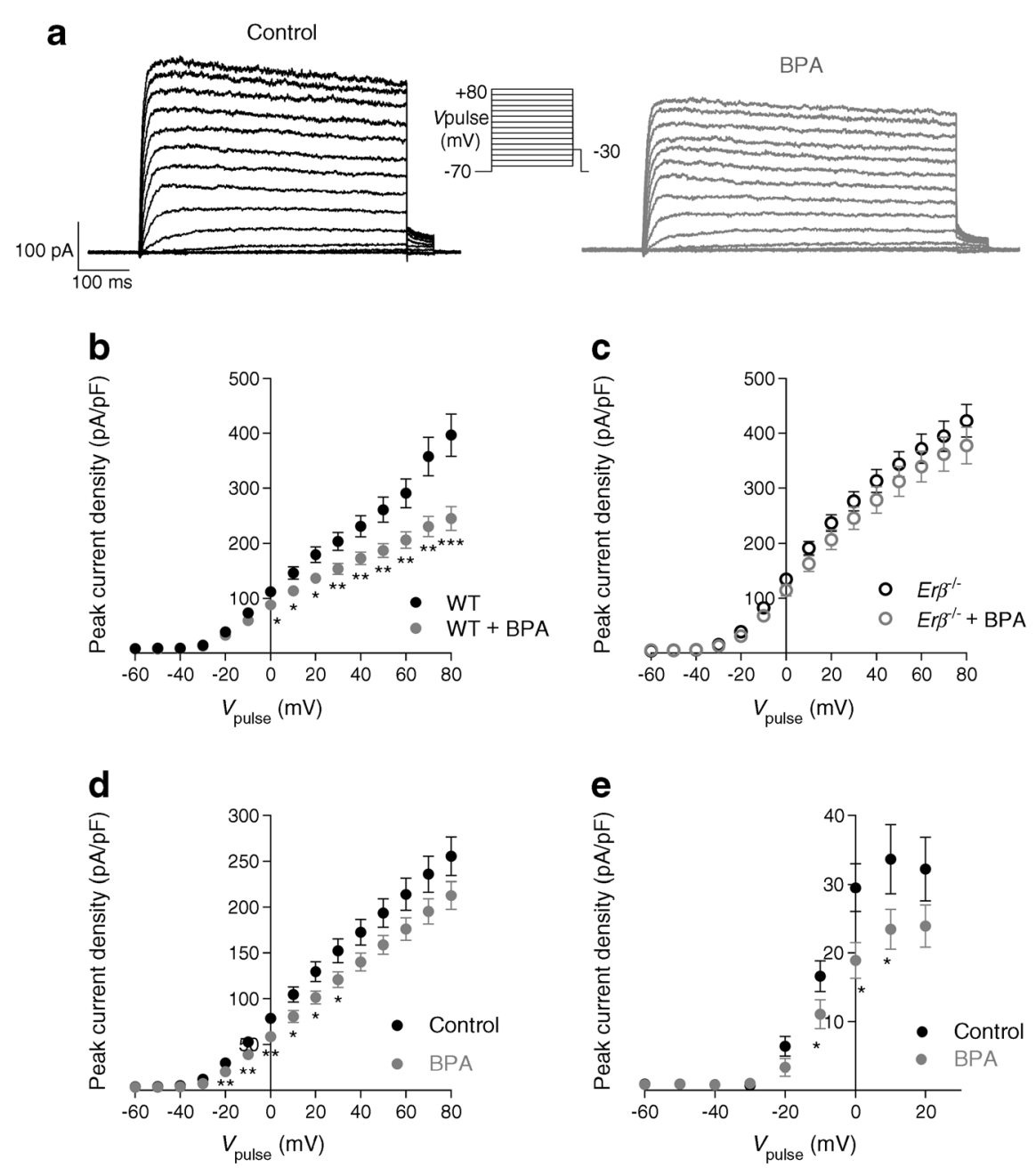

Fig. 4 BPA inhibits $\mathrm{K}^{+}$currents in mouse pancreatic beta cells. (a) Representative recordings of $\mathrm{K}^{+}$currents in response to depolarising voltage pulses $(-60 \mathrm{mV}$ to $+80 \mathrm{mV}$ from a holding potential of $-70 \mathrm{mV}$, $500 \mathrm{~ms}$ duration [inset]) in isolated beta cells treated with vehicle (control) or BPA $1 \mathrm{nmol} / 1$ for $48 \mathrm{~h}$. (b, c) Relationship between $\mathrm{K}^{+}$current density $\left(\mathrm{K}^{+}\right.$currents in $\mathrm{pA}$ normalised to the cell capacitance in $\left.\mathrm{pF}\right)$ and the voltage of the pulses in dispersed cells from wild-type (WT) (b) and $\operatorname{Er} \beta^{-1-}$ (c) mice treated ex vivo with vehicle (control; $n=15$ beta cells) or BPA $1 \mathrm{nmol} / 1$ ( $n=18$ beta cells) for $48 \mathrm{~h}$. (d) Relationship between $\mathrm{K}^{+}$

current density $\left(\mathrm{K}^{+}\right.$currents in $\mathrm{pA}$ normalised to the cell capacitance in $\mathrm{pF}$ ) and the voltage of the pulses in dispersed cells treated ex vivo with vehicle (control; $n=11$ beta cells) or BPA $1 \mathrm{nmol} / 1$ ( $n=11$ beta cells) for $48 \mathrm{~h}$ in the presence of IbTX $(100 \mathrm{nmol} / \mathrm{l})$ to block $\mathrm{K}_{\mathrm{Ca}} 1.1$ currents. (e) The same experiment as in (d) but in the presence of ScTx $(100 \mathrm{nmol} / \mathrm{l})$ to block $\mathrm{K}_{\mathrm{v}} 2.1 / 2.2$ currents. Data are shown as means \pm SEM of the number of cells recorded. Cells were isolated from five (b), two (c), or four $(\mathbf{d}, \mathbf{e})$ mice on at least three different days: $* p \leq 0.05, * * p \leq 0.01, * * * p \leq 0.001$ vs control at the same $V_{\text {pulse }}$ (Student's $t$ test)

Table 1, ESM Fig. 2). To determine which $\mathrm{K}^{+}$-channel subtypes were altered by BPA exposure, we measured $\mathrm{K}^{+}$current in mouse beta cells in the absence or presence of iberiotoxin (IbTx, a specific blocker of $\mathrm{K}_{\mathrm{Ca}} 1.1$ channels), or stromatoxin1 ( $\mathrm{ScTx} 1$, a selective inhibitor of the homotetrameric $\mathrm{K}_{\mathrm{v}} 2.1$ and $\mathrm{K}_{\mathrm{v}} 2.2$ channels). In the presence of $100 \mathrm{nmol} / 1 \mathrm{IbTx}$, the peak current density was decreased by BPA, although to a lesser extent than in the absence of the blocker (Fig. 4d). Similarly, BPA diminished $\mathrm{K}^{+}$currents even in the presence of ScTx1 $100 \mathrm{nmol} / \mathrm{l}$ (Fig. 4e). These results show that BPA reduces both $\mathrm{K}_{\mathrm{v}} 2.1 / 2.2$ and $\mathrm{K}_{\mathrm{Ca}} 1.1$ channel subtypes, consistent with the BPA-induced downregulation of Kcnb2 and Kcnma1. To evaluate whether the effects of BPA on $\mathrm{K}^{+}$ currents were due to its oestrogenic activity, we measured $\mathrm{K}^{+}$currents in control and $17 \beta$-oestradiol-treated cells. Surprisingly, contrary to its effect on $\mathrm{Na}^{+}$currents (ESM Fig. 2a,b), 17ß-oestradiol did not modify $\mathrm{K}^{+}$currents (ESM Fig. 5).

BPA alters electrical activity The electrical activity in response to an increase in the external glucose concentration (from $0 \mathrm{mmol} / \mathrm{l}$ to $11 \mathrm{mmol} / \mathrm{l}$ ) was recorded from dissociated beta cells using the perforated patch-clamp technique (see details in ESM Fig. 6). Compared with vehicle-treated control beta cells (Fig. 5a), BPA treatment altered the characteristic single burst of dissociated beta cells (Fig. 5b). The burst duration, 

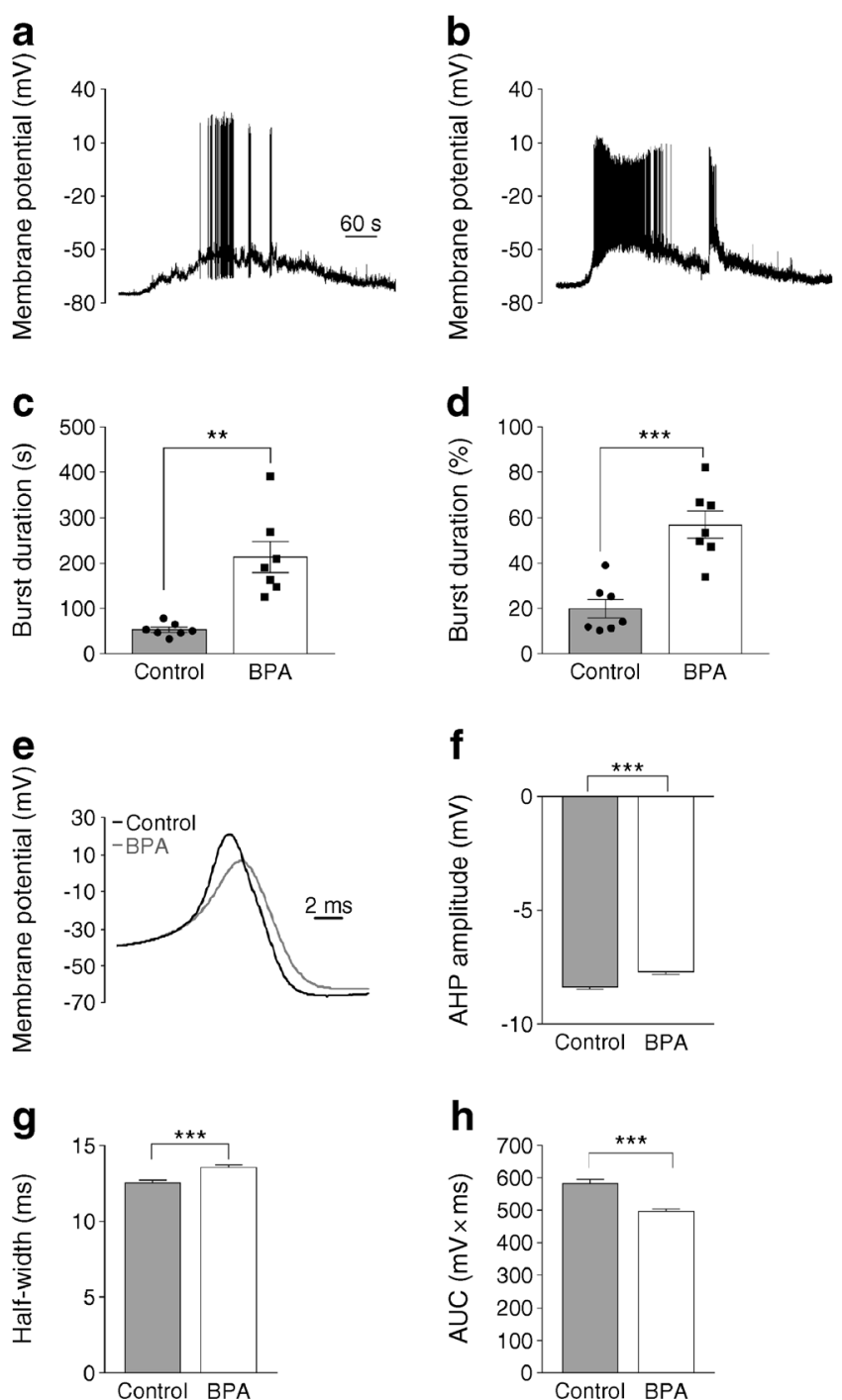

Fig. 5 BPA alters glucose-induced electrical activity in mouse pancreatic beta cells. (a, b) Response of pancreatic beta cell electrical activity to a stimulatory glucose level $(11 \mathrm{mmol} / \mathrm{l})$, recorded using the perforated patch-clamp technique in dispersed cells treated ex vivo with vehicle (control, $n=15$ beta cells) (a) or BPA $1 \mathrm{nmol} / \mathrm{l}(n=18$ beta cells) (b) for $48 \mathrm{~h}$. (c) Burst duration at $11 \mathrm{mmol} / \mathrm{l}$ glucose in dispersed cells treated ex vivo with vehicle (control, $n=7$ beta cells) or BPA $1 \mathrm{nmol} / \mathrm{l}(n=7$ beta cells) for $48 \mathrm{~h}$. (d) The same experiment as in (c) but expressed as percentage of burst duration vs time depolarised at $11 \mathrm{mmol} / /$ glucose. Data in $(\mathbf{c}, \mathbf{d})$ are shown as the means \pm SEM of the number of cells recorded. Cells were isolated from seven mice on at least three different days: $* * p \leq 0.01, * * * p \leq 0.001$ (Student's $t$ test). (e) Superimposed representative action potentials at $11 \mathrm{mmol} / 1$ glucose in dispersed beta cells treated ex vivo with vehicle (control) or BPA $1 \mathrm{nmol} / \mathrm{l}$ for $48 \mathrm{~h}$. (f) After-hyperpolarisation (AHP) amplitude following action potentials in dispersed beta cells treated ex vivo with vehicle (control; 1600 action potentials from $n=11$ beta cells) or BPA $1 \mathrm{nmol} / \mathrm{l}$ (1780 action potentials from $n=11$ beta cells) for $48 \mathrm{~h}$. (g) Action potential half-width in dispersed beta cells treated ex vivo with vehicle (control; 1452 action potentials from $n=11$ beta cells) or BPA $1 \mathrm{nmol} / 1$ (1342 action potentials from $n=11$ beta cells) for $48 \mathrm{~h}$. (h) AUC of action potential area in dispersed beta cells treated ex vivo with vehicle (control; 1780 action potentials from $n=11$ beta cells) or BPA $1 \mathrm{nmol} / \mathrm{l}$ (1780 action potentials from $n=11$ beta cells) for $48 \mathrm{~h}$. Data in (f-h) are shown as the means \pm SEM of the number of cells recorded. These cells were isolated from five mice on at least three different days: $* * * p \leq 0.001$ (Student's $t$ test) measured as the time of action potential firing (Fig. $5 \mathrm{c}$ ) or as the percentage of time firing action potentials in the burst (Fig. $5 \mathrm{~d}$ ), was increased by BPA. As previously shown, a reduction in the amplitude of action potentials was due to decreased $\mathrm{Ca}^{2+}$ currents after BPA-induced $\mathrm{Ca}_{\mathrm{v}} 2.3$ downregulation. Here we show that BPA reduced the amplitude of the action potential after hyperpolarisation (Fig. 5e,f) and enlarged the half-width of the action potential (Fig. $5 \mathrm{~g}$ ), indicating that BPA induced a reduction in $\mathrm{K}^{+}$currents as reported above. Furthermore, because of the changes in the action potential waveform, the AUC of the action potential also diminished (Fig. 5h).

\section{Discussion}

Pancreatic beta cells encode information with electrical signals. In response to glucose, beta cells produce bursts of action potentials, generated by the activation of ion channels expressed in their membrane, which ultimately stimulate insulin secretion. Thus, any alteration in the expression and/or activation of ion channels in beta cells leads to alteration of insulin secretion and disturbance of glucose homeostasis. Our findings indicate that environmentally relevant doses of BPA alter ion channel expression in beta cells in an ER $\beta$-dependent manner. Consequently, whole-cell $\mathrm{Ca}^{2+}[23], \mathrm{K}^{+}$and $\mathrm{Na}^{+}$currents were reduced, altering the shape of action potentials and modifying beta cell electrical activity. Studies in humans and animal models suggest that anomalies in beta cell function, including alterations of beta cell electrical activity, play important roles in the aetiology of type 2 diabetes [33,34]. Thus, the changes in the expression and activity of ion channels described herein might contribute to the diabetogenic action of BPA observed in animal models $[16,35,36]$ and in epidemiological human studies [37-39].

Microarray analysis indicated that the expression of more than 50 genes encoding ion channel subunits were either upregulated or downregulated in response to BPA treatment in vivo. It has been shown that the treatment used here induces insulin resistance and hyperinsulinaemia in the non-fasted state $[16,18]$. This BPA dose can be considered low as it is only twice the 'reference dose' ( $50 \mu \mathrm{g} / \mathrm{kg}$ per day) believed by the US Environmental Protection Agency to be safe over a lifetime. An oral dose of BPA equal to this reference dose rapidly altered GSIS, decreasing GSIS second phase in obese individuals (mean BMI $31 \mathrm{~kg} / \mathrm{m}^{2}$ ) [40]. In 2015, the European Union reduced the tolerable BPA daily intake to $4 \mu \mathrm{g} / \mathrm{kg}$ [41].

The changes in gene expression observed in vivo were reproduced in primary cultured beta cells treated with BPA $1 \mathrm{nmol} / \mathrm{l}$. Of note, this BPA concentration is similar to that found in human serum [20]. The fact that BPA alters ion channel expression in primary cells indicates that BPA acts directly on beta cells and, therefore, the changes observed 
Table 1 Microarray results showing genes related to ion channel subunits differentially expressed between vehicle- and BPA-treated mice

\begin{tabular}{|c|c|c|c|c|c|}
\hline Affymetrix ID & Symbol & Name & $\begin{array}{l}\text { Fold change } \\
\text { (linear) }^{\mathrm{a}}\end{array}$ & Up/Down ${ }^{\text {b }}$ & $p$ value \\
\hline 1416956_at & Kcnab2 & Potassium voltage-gated channel, shaker-related subfamily, beta member 2 & 1.2476 & Up & $0.0197 *$ \\
\hline 1422871_at & Kcnj12 & Potassium inwardly rectifying channel, subfamily J, member 12 & 1.2790 & Down & $0.0299 *$ \\
\hline 1425090_s_at & Kcnc4 & Potassium voltage-gated channel, Shaw-related subfamily, member 4 & 1.2227 & Up & $0.0394 *$ \\
\hline 1436275_at & Kcnip2 & Kv channel-interacting protein 2 & 1.1990 & Up & $0.0458 *$ \\
\hline 1447418_at & Kcnq1 & Potassium voltage-gated channel, subfamily Q, member 1 & 1.3404 & Up & $0.0029 * *$ \\
\hline 1451595_a_at & Kcnq2 & Potassium voltage-gated channel, subfamily Q, member 2 & 1.2349 & Up & $0.0235^{*}$ \\
\hline 1451808 at & Kcnj4 & Potassium inwardly rectifying channel, subfamily $\mathrm{J}$, member 4 & 1.1710 & Up & $0.0307 *$ \\
\hline 1457152_at & Kcnb2 & Potassium voltage-gated channel, Shab-related subfamily, member 2 & 1.9101 & Down & $0.0184 *$ \\
\hline 1458781_at & Kcnk13 & Potassium channel, subfamily K, member 13 & 1.2643 & Down & $0.0110 *$ \\
\hline 1440728_at & Kcnmal & $\begin{array}{l}\text { Potassium large-conductance calcium-activated channel, subfamily M, } \\
\text { alpha member } 1\end{array}$ & 1.8547 & Down & 0.1541 \\
\hline 1421762_at & Kcnj5 & Potassium inwardly rectifying channel, subfamily J, member 5 & 1.1236 & Up & 0.1008 \\
\hline 1416785_at & Kcnipl & Kv channel-interacting protein 1 & 1.3834 & Up & 0.0732 \\
\hline 1454504_at & Kcnipl & $\mathrm{Kv}$ channel-interacting protein 1 & 1.1438 & Down & 0.1488 \\
\hline 1421038_a_at & Kcnn4 & $\begin{array}{l}\text { Potassium intermediate/small-conductance calcium-activated channel, } \\
\text { subfamily N, member } 4\end{array}$ & 1.1745 & $\mathrm{Up}$ & 0.0774 \\
\hline 1421518_at & Kcns1 & $\mathrm{K}+$ voltage-gated channel, subfamily $\mathrm{S}, 1$ & 1.1587 & Up & 0.1943 \\
\hline 1421619_at & Kcnh3 & Potassium voltage-gated channel, subfamily H (eag-related), member 3 & 1.1148 & Up & 0.1554 \\
\hline 1423179_at & Kcnb1 & Potassium voltage-gated channel, Shab-related subfamily, member 1 & 1.2613 & Down & 0.0559 \\
\hline 1423950_at & Kcnab3 & Potassium voltage-gated channel, shaker-related subfamily, beta member 3 & 1.1621 & Up & 0.1338 \\
\hline 1434838_at & Kcng2 & Potassium voltage-gated channel, subfamily G, member 2 & 1.1154 & Up & 0.1787 \\
\hline 1435342_at & Kcnk6 & Potassium inwardly rectifying channel, subfamily K, member 6 & 1.1731 & Up & 0.1549 \\
\hline 1435994_at & Kcnh1 & Potassium voltage-gated channel, subfamily H (eag-related), member 1 & 1.2855 & Up & 0.0904 \\
\hline 1437631_at & Kcnip4 & Kv channel-interacting protein 4 & 1.4100 & Up & 0.0793 \\
\hline 1438613_at & Kcna4 & Potassium voltage-gated channel, shaker-related subfamily, member 4 & 1.1025 & Up & 0.1270 \\
\hline 1443855_at & Kcncl & Potassium voltage-gated channel, Shaw-related subfamily, member 1 & 1.1791 & Down & 0.1849 \\
\hline 1450712_at & Kcnj9 & Potassium inwardly rectifying channel, subfamily J, member 9 & 1.2029 & Up & 0.1105 \\
\hline 1450773_at & Kcnd2 & Potassium voltage-gated channel, Shal-related family, member 2 & 1.1453 & Down & 0.0839 \\
\hline 1453273_at & Kcnv1 & Potassium channel, subfamily V, member 1 & 1.1089 & Up & 0.1512 \\
\hline 1454043_a_at & Kcnabl & Potassium voltage-gated channel, shaker-related subfamily, beta member 1 & 1.1660 & Up & 0.0856 \\
\hline 1454768_at & Kcnfl & Potassium voltage-gated channel, subfamily F, member 1 & 1.2682 & Up & 0.0781 \\
\hline 1455258_at & Kcnc2 & Potassium voltage-gated channel, Shaw-related subfamily, member 2 & 1.1891 & Down & 0.1366 \\
\hline 1455514_at & Kcnd1 & Potassium voltage-gated channel, Shal-related family, member 1 & 1.1907 & $\mathrm{Up}$ & 0.1266 \\
\hline 1459308_at & Kcnn3 & $\begin{array}{l}\text { Potassium intermediate/small conductance calcium-activated channel, } \\
\text { subfamily N, member } 3\end{array}$ & 1.2065 & Down & 0.1581 \\
\hline 1455765_a_at & $A b c c 8$ & ATP-binding cassette, subfamily C (CFTR/MRP), member 8 & 1.0076 & Up & 0.9912 \\
\hline 1450515_at & Kcnj11 & Potassium inwardly rectifying channel, subfamily J, member 11 & 1.0856 & Down & 0.9190 \\
\hline 1442333_a_at & $\operatorname{Scn} 9 a$ & Sodium channel, voltage-gated, type IX, alpha & 2.5511 & Down & $0.0014 * *$ \\
\hline 1421705_at & $\operatorname{Scn} 3 a$ & Sodium channel, voltage-gated, type III, alpha & 1.0387 & Down & 0.5566 \\
\hline 1441608_at & Cacna2d1 & Calcium channel, voltage-dependent, alpha2/delta subunit 1 & 1.8741 & Down & $0.0266^{*}$ \\
\hline
\end{tabular}

Islets from vehicle- and BPA-treated mice were isolated and a microarray analysis was performed

${ }^{a}$ Changes between islets from BPA-treated mice and islets from vehicle-treated mice. Differentially expressed genes were selected using a linear model approach and implemented in the Linear Models for Microarray Bioconductor package (http://www.bioconductor.org; R package version 2.7.0)

${ }^{\mathrm{b}}$ Direction of gene regulation

$*_{p}<0.05 ; * *<0.01$

in vivo are not the result of islet adaptation to counteract insulin resistance. Nonetheless, we cannot completely discount some indirect effects of BPA in our in vivo results.
Voltage-activated $\mathrm{K}^{+}$channels are responsible for the outward currents underlying the falling phase of the action potential [42]. Kcnb2, encoding the $\mathrm{K}_{\mathrm{v}} 2.2$ channel, is involved in 


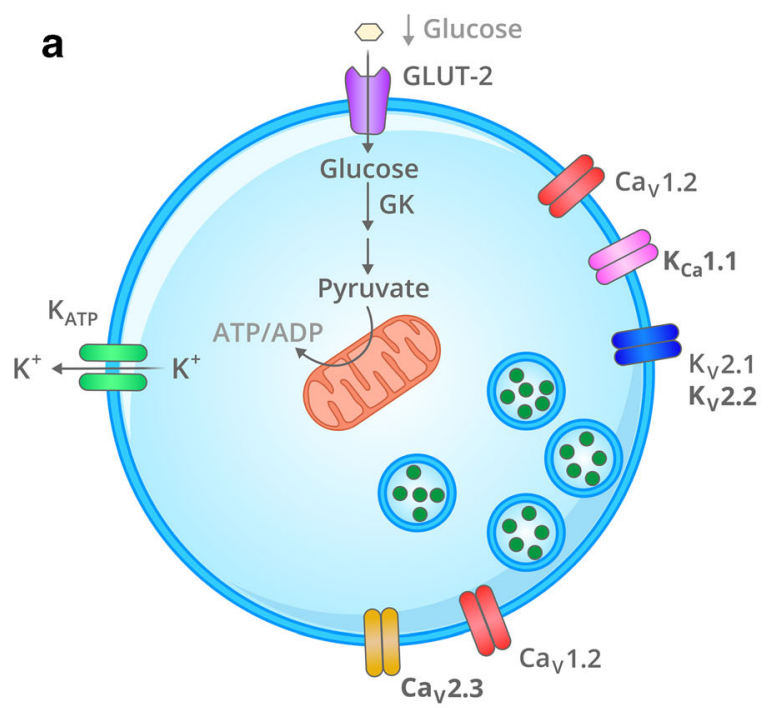

Fig. 6 Stimulus-secretion coupling model showing $\mathrm{Ca}^{2+}$ and $\mathrm{K}^{+}$channels downregulated by BPA in mouse pancreatic beta cells. (a) The main ion channels involved in glucose-induced electrical activity in mouse pancreatic beta cells. The $\mathrm{K}_{\text {ATP }}$ channel is responsible for the resting membrane potential and the voltage-gated $\mathrm{Ca}_{\mathrm{v}} 1.2, \mathrm{Ca}_{\mathrm{v}} 2.3, \mathrm{~K}_{\mathrm{v}} 2.1, \mathrm{~K}_{\mathrm{v}} 2.2$ and $\mathrm{K}_{\mathrm{Ca}} 1.1$ channels remain closed in the absence of stimuli. BPA downregulates the expression and the currents mediated by $\mathrm{Ca}_{\mathrm{v}} 2.3$ (see [23]), $\mathrm{K}_{\mathrm{v}} 2.2$, and $\mathrm{K}_{\mathrm{Ca}} 1.1$ channels. (b) Upon an increase in extracellular glucose levels, glucose enters the cell and is metabolised, which causes a

the mouse beta cell electrical activity and its inhibition impairs GSIS [43]. Here, Kcnb2 expression was decreased by BPA both in vivo and ex vivo. The related channel $\mathrm{K}_{\mathrm{v}} 2.1$ (encoded by $K c n b 1$ ) is responsible for most of the outward current during action potential repolarisation and its ablation increases insulin release [31, 44]. However, the expression of Kcnb1 did not significantly change upon BPA exposure. BPA treatment also decreased expression of Kcnipl, which encodes the major $\beta$-subunit of $\mathrm{K}_{\mathrm{v}}$ channels expressed in mouse beta cells [32]. Although the role of Kcnipl is poorly understood, silencing of Kcnip1 potentiates GSIS without altering insulin transcription in MIN6N8 beta cells [32].

Our patch-clamp experiments showed that BPA reduced $\mathrm{K}^{+}$ outward currents. To study BPA's effects on $\mathrm{K}_{\mathrm{v}}$ channels in isolation, we blocked the $\mathrm{K}_{\mathrm{Ca}} 1.1$ channel (which would be activated with the voltage-clamp protocol employed) with iberiotoxin. We observed a reduction in BPA-induced voltage-activated $\mathrm{K}^{+}$currents. However, we cannot differentiate between the closely related $\mathrm{K}_{\mathrm{v}} 2.1$ and $\mathrm{K}_{\mathrm{v}} 2.2$ channels in these experiments. The BPA-induced decrease in $\mathrm{K}^{+}$current could be caused by the diminished expression of $\mathrm{K}_{\mathrm{v}} 2.2$ channel subunits, although we cannot rule out a BPA-elicited change in the biophysical properties of some $\mathrm{K}^{+}$channels, particularly the $\mathrm{K}_{\mathrm{v}} 2.1$ channel whose gene expression remained unchanged.

In addition to the effect of BPA in voltage-activated $\mathrm{K}_{\mathrm{v}} 2.1$ / $\mathrm{K}_{\mathrm{v}} 2.2$ channels, we investigated whether BPA affected $\mathrm{K}_{\mathrm{Ca}} 1.1$ channels, which are critical in action potential shaping [6]. For

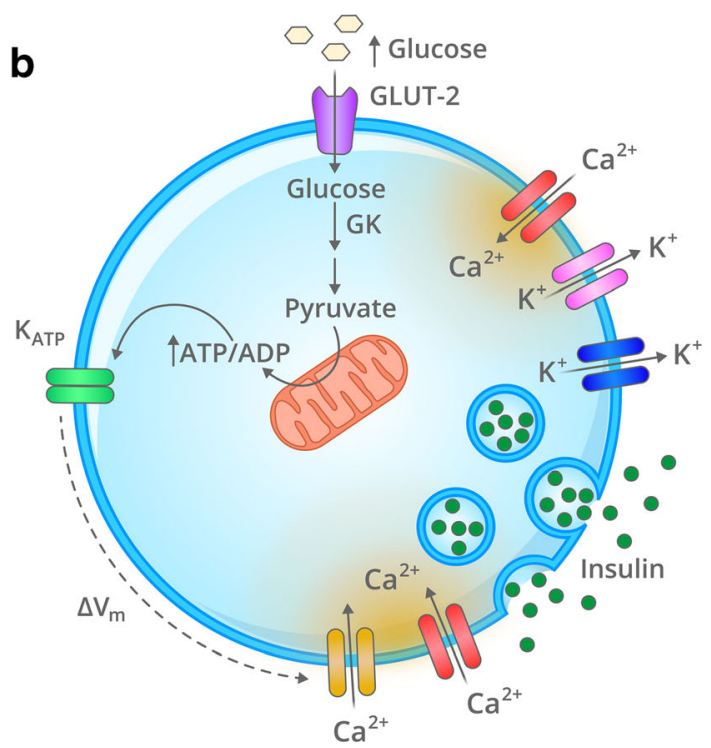

rise in the ATP:ADP ratio. Subsequently, $\mathrm{K}_{\mathrm{ATP}}$ channels are closed, leading to membrane depolarisation and opening of the voltage-gated $\mathrm{Ca}^{2+}$ and $\mathrm{K}^{+}$channels. The subsequent $\mathrm{Ca}^{2+}$ influx triggers insulin release. BPA-induced downregulation of $\mathrm{Ca}_{\mathrm{v}} 2.3, \mathrm{~K}_{\mathrm{v}} 2.2$ and $\mathrm{K}_{\mathrm{Ca}} 1.1$ channels helps to explain the modified shape of the action potential elicited by BPA (Fig. 5e), which culminates in increased insulin release. Note that the $\mathrm{Na}^{+}$channels $\mathrm{Na}_{\mathrm{v}} 1.3$ and $\mathrm{Na}_{\mathrm{v}} 1.7$ are not included because their role in the stimulus-secretion coupling model is still unclear. GK, glucokinase; $V_{\mathrm{m}}$, membrane potential

this purpose, we employed ScTx 1 as a blocker of $\mathrm{K}_{\mathrm{v}} 2.1 / \mathrm{K}_{\mathrm{v}} 2.2$ channels. Our results indicate that BPA decreased a fraction of the large outward current that was resistant to ScTx1 and hence carried by $\mathrm{K}_{\mathrm{Ca}} 1.1$ channels, indicating that $\mathrm{K}_{\mathrm{Ca}} 1.1$ channels are sensitive to BPA. This effect could be attributed to the BPA-induced downregulation of Kcnmal, which encodes the $\alpha 1$ subunit of $\mathrm{K}_{\mathrm{Ca}} 1.1$ channels. $\mathrm{K}_{\mathrm{Ca}} 1.1$ channels are $\mathrm{Ca}^{2+}$ - and voltage-dependent channels that, in mouse beta cells, play a part mostly in cells with large $\mathrm{Ca}^{2+}$ currents, in which $\mathrm{K}_{\mathrm{Ca}} 1.1$ channel blockade increased spike amplitude and potentiated GSIS [10].

Changes in the expression of $\mathrm{K}_{\mathrm{v}}$ and $\mathrm{K}_{\mathrm{Ca}} 1.1$ channel subunits could explain the change in the shape of action potentials and the alteration of the electrical activity pattern induced by BPA exposure. The decreased activity of $\mathrm{Ca}_{\mathrm{v}} 2.3$ channels in the presence of $1 \mathrm{nmol} / 1 \mathrm{BPA}$ [23] could be responsible for the diminished amplitude of the action potential. A decrease in $\mathrm{Ca}^{2+}$ entry would contribute to a diminished activation of $\mathrm{K}_{\mathrm{Ca}} 1.1$ channels that, together with downregulation of $\mathrm{K}_{\mathrm{Ca}} 1.1$ and $\mathrm{K}_{\mathrm{v}} 2.2$ channels, results in wider action potentials. Given the role of $\mathrm{K}^{+}$current in beta cell electrical activity [6], this effect of BPA exposure should cause longer bursts of electrical activity (present data) and may explain, at least partially, the enhanced GSIS already described in BPA-exposed beta cells $[16,17,23]$.

Mouse beta cells express two main types of $\mathrm{Na}^{+}$channels, $\mathrm{Na}_{\mathrm{v}} 1.3$ and $\mathrm{Na}_{\mathrm{v}} 1.7$, whose roles are less understood compared 
with $\mathrm{Ca}^{2+}$ and $\mathrm{K}^{+}$channels. The $\mathrm{Na}_{\mathrm{v}} 1.3$ channel is responsible for only a small part of the total $\mathrm{Na}^{+}$current and it may play a role in the depolarisation of the action potential [30]. Alternatively, the $\mathrm{Na}_{\mathrm{v}} 1.7$ channel, encoded by $S c n 9 a$, corresponds to $85 \%$ of the $\mathrm{Na}^{+}$current [30], although its role is yet to be unveiled as the $\mathrm{Na}_{\mathrm{v}} 1.7$ channel is inactivated at physiological membrane potentials. While no alterations in GSIS are observed in $\operatorname{Scn} 9 a^{-/-}$mice, these mice present higher insulin content relative to wild-type counterparts [12]. Furthermore, $\mathrm{Na}_{\mathrm{v}} 1.7$ channel inhibition increases both Ins 1 and Ins 2 mRNA expression [12]. These data suggest that $\mathrm{Na}_{\mathrm{v}} 1.7$ channels may be associated with insulin biosynthesis. It has been shown that BPA augments insulin content through an ER $\alpha / E R K$ pathway [17]. However, it remains to be determined whether the BPAinduced $S n c 9 a$ downregulation observed in the present study is associated with the increase in insulin content observed in BPA-treated beta cells.

Of note, our experiments using beta cells from $\operatorname{Er} \beta^{-1-}$ mice indicated that BPA decreased Scn9a, Kcnb2 and Kcnmal expression, as well as $\mathrm{Na}^{+}$and $\mathrm{K}^{+}$currents, in an ER $\beta$-dependent manner. The use of a global $\operatorname{Er} \beta$ knockout may represent a handicap in our study as the ER $\beta$ receptor is important for other tissues involved in glucose homeostasis. Hence, it might be suggested that the absence of ER $\beta$ could indirectly affect beta cells in vivo. Nevertheless, this in vivo component seems unlikely in our model, at least considering the ion channels studied herein. If we carefully analyse the current-voltage curves for beta cells from wild-type and $E r \beta^{-/-}$mice, we can see that they are identical. Moreover, our data with DPN, an ER $\beta$ agonist, fully reproduced BPA's effects on $\mathrm{Na}^{+}$and $\mathrm{K}^{+}$ currents, reinforcing the role played by ER $\beta$ in the BPAinduced changes identified in beta cells. Of note, our findings do not rule out the involvement of other oestrogen receptors, such as ER $\alpha$ and G protein-coupled oestrogen receptor 1 (GPER), in the pathway activated by BPA.

The changes in the expression of ion channel subunits, ion channel-mediated currents and electrical activity presented here suggest that low doses of BPA alter beta cell function via $E R \beta$. These effects of BPA could be responsible, at least in part, for the previously described increase in GSIS in vivo and ex vivo $[16,17,23]$. Moreover, $\mathrm{Na}_{\mathrm{v}} 1.7$ channel downregulation opens the possibility of a new regulatory pathway activated by $E R \beta$ to regulate insulin biosynthesis. As the BPA concentration used herein was similar to that found in the human population, these results reinforce the likely diabetogenic action of BPA.

Thus, our present results establish a mechanistic link to explain the BPA-induced enhancement in GSIS, placing the main channels involved in beta cell electrical activity as key targets of a diabetogenic EDC (Fig. 6). Moreover, understanding how BPA regulates the shape of action potentials in beta cells is important for revealing the mechanisms by which this EDC acts in other excitable cells, including neurons and cardiac, skeletal and smooth muscle cells. This may be relevant to explain the actions of BPA on the nervous system and its effects in cardiovascular disease [45].

Acknowledgements The authors thank M. L. Navarro, S. Ramon and D. Navarro (IBMC/IDiBE, Universitas Miguel Hernández) for their excellent technical assistance.

Data availability The data presented in this publication have been deposited in NCBI's Gene Expression Omnibus (GEO) and are accessible through GEO Series accession number GSE126297 [46].

Funding This work was supported by Ministerio de Economía y Competitividad, Agencia Estatal de Investigación (AEI) and Fondo Europeo de Desarrollo Regional (FEDER) grants BPU2017-86579-R and SAF2014-58335-P (AN) and BFU2016-77125-R (IQ); Generalitat Valenciana PROMETEO II/2015/016 (AN); Grant for Networks of Excellence from MICINN 'Nuclear Receptors in Cancer, Metabolism and Inflammation' (NuRCaMeIn) (SAF2017-90604-REDT); Spanish Institute of Health Carlos III grants PI16/00259 (AH), PI17/02104 and RD16/0011/0034 (BS) co-financed by FEDER Funds. LM holds a Juan de la Cierva fellowship from the Ministry of Economy, Industry and Competitiveness (IJCI-2015-24482). CIBERDEM is an initiative of the Instituto de Salud Carlos III. J-AG was supported by the Robert A. Welch Foundation (E-0004).

Duality of interest The authors declare that there is no duality of interest associated with this manuscript.

Contribution statement JM-P, LM and AN conceived the study. JM-P, LM, AH, JL-B, SS, SV-P, FM and PA-M collected and analysed the data. JM-P, LM, SS, SV-P, PA-M, RSDS, IQ, BS, J-AG, JM-P and AN interpreted the data. JM-P, RSDS and AN drafted the manuscript. AN supervised the study. RSDS, IQ, J-AG critically revised the manuscript for important intellectual content. AH, IQ, BS, J-AG and AN acquired the funding. All authors reviewed and approved the final version of the manuscript, and gave consent to publication. AN is responsible for the integrity of the work as a whole.

\section{References}

1. World Health Organization (2018) Diabetes. Available from https:// www.who.int/news-room/fact-sheets/detail/diabetes. Accessed 20 Oct 2018

2. Ashcroft FM, Harrison DE, Ashcroft SJ (1984) Glucose induces closure of single potassium channels in isolated rat pancreatic $\beta$ cells. Nature 312(5993):446-448. https://doi.org/10.1038/ $312446 \mathrm{a} 0$

3. Dean PM, Matthews EK (1968) Electrical activity in pancreatic islet cells. Nature 219(5152):389-390. https://doi.org/10.1038/ 219389a0

4. Dean PM, Matthews EK (1970) Glucose-induced electrical activity in pancreatic islet cells. J Physiol 210(2):255-264. https://doi.org/ 10.1113/jphysiol.1970.sp009207

5. Santos RM, Rosario LM, Nadal A, Garcia-Sancho J, Soria B, Valdeolmillos M (1991) Widespread synchronous $\left[\mathrm{Ca}^{2+}\right]_{\mathrm{i}}$ oscillations due to bursting electrical activity in single pancreatic islets. Pflugers Arch 418(4):417-422. https://doi.org/10.1007/ BF00550880 
6. Rorsman P, Ashcroft FM (2018) Pancreatic $\beta$-cell electrical activity and insulin secretion: of mice and men. Physiol Rev 98(1):117214. https://doi.org/10.1152/physrev.00008.2017

7. Herrington J, Zhou YP, Bugianesi RM et al (2006) Blockers of the delayed-rectifier potassium current in pancreatic $\beta$-cells enhance glucose-dependent insulin secretion. Diabetes 55(4):1034-1042. https://doi.org/10.2337/diabetes.55.04.06.db05-0788

8. MacDonald PE, Wheeler MB (2003) Voltage-dependent $\mathrm{K}^{+}$channels in pancreatic beta cells: role, regulation and potential as therapeutic targets. Diabetologia 46(8):1046-1062. https://doi.org/10. 1007/s00125-003-1159-8

9. Roe MW, Worley JF 3rd, Mittal AA et al (1996) Expression and function of pancreatic $\beta$-cell delayed rectifier $\mathrm{K}^{+}$channels. Role in stimulus-secretion coupling. J Biol Chem 271(50):32241-32246. https://doi.org/10.1074/jbc.271.50.32241

10. Houamed KM, Sweet IR, Satin LS (2010) BK channels mediate a novel ionic mechanism that regulates glucose-dependent electrical activity and insulin secretion in mouse pancreatic $\beta$-cells. J Physiol 588(Pt 18):3511-3523. https://doi.org/10.1113/jphysiol.2009. 184341

11. Gopel S, Kanno T, Barg S, Galvanovskis J, Rorsman P (1999) Voltage-gated and resting membrane currents recorded from B cells in intact mouse pancreatic islets. J Physiol 521(3):717-728. https:// doi.org/10.1111/j.1469-7793.1999.00717.x

12. Szabat M, Modi H, Ramracheya R et al (2015) High-content screening identifies a role for $\mathrm{Na}^{+}$channels in insulin production. R Soc Open Sci 2(12):150306. https://doi.org/10.1098/rsos.150306

13. Yang YH, Vilin YY, Roberge M, Kurata HT, Johnson JD (2014) Multiparameter screening reveals a role for $\mathrm{Na}^{+}$channels in cytokine-induced $\beta$-cell death. Mol Endocrinol 28(3):406-417. https://doi.org/10.1210/me.2013-1257

14. Skelin Klemen M, Dolensek J, Slak Rupnik M, Stozer A (2017) The triggering pathway to insulin secretion: Functional similarities and differences between the human and the mouse beta cells and their translational relevance. Islets 9(6):109-139. https://doi.org/10. 1080/19382014.2017.1342022

15. Gopel SO, Kanno T, Barg S et al (1999) Activation of $\mathrm{Ca}^{2+}$-dependent $\mathrm{K}^{+}$channels contributes to rhythmic firing of action potentials in mouse pancreatic beta cells. J Gen Physiol 114(6):759-770. https://doi.org/10.1085/jgp.114.6.759

16. Alonso-Magdalena P, Morimoto S, Ripoll C, Fuentes E, Nadal A (2006) The estrogenic effect of bisphenol A disrupts pancreatic $\beta$ cell function in vivo and induces insulin resistance. Environ Health Perspect 114(1):106-112. https://doi.org/10.1289/ehp.8451

17. Alonso-Magdalena P, Ropero AB, Carrera MP et al (2008) Pancreatic insulin content regulation by the estrogen receptor ER alpha. PLoS One 3(4):e2069. https://doi.org/10.1371/journal.pone. 0002069

18. Batista TM, Alonso-Magdalena P, Vieira E et al (2012) Short-term treatment with bisphenol-A leads to metabolic abnormalities in adult male mice. PLoS One 7(3):e33814. https://doi.org/10.1371/ journal.pone. 0033814

19. Soriano S, Alonso-Magdalena P, Garcia-Arevalo M et al (2012) Rapid insulinotropic action of low doses of bisphenol-A on mouse and human islets of Langerhans: role of estrogen receptor beta. PLoS One 7(3):e31109. https://doi.org/10.1371/journal.pone. 0031109

20. Calafat AM, Ye X, Wong LY, Reidy JA, Needham LL (2008) Exposure of the U.S. population to bisphenol A and 4-tertiaryoctylphenol: 2003-2004. Environ Health Perspect 116(1):39-44. https://doi.org/10.1289/ehp.10753

21. Olsen L, Lampa E, Birkholz DA, Lind L, Lind PM (2012) Circulating levels of bisphenol A (BPA) and phthalates in an elderly population in Sweden, based on the Prospective Investigation of the Vasculature in Uppsala Seniors (PIVUS). Ecotoxicol Environ Saf 75(1):242-248. https://doi.org/10.1016/j.ecoenv.2011.09.004
22. European Chemicals Agency (ECHA) (2018) Seven new substances added to the Candidate List, entry for bisphenol-A updated. Available from https://echa.europa.eu/es/-/seven-new-substancesadded-to-the-candidate-list-entry-for-bisphenol-a-updated-toreflect-its-endocrine-disrupting-properties-for-the-environment. Accessed 10 Oct 2018

23. Villar-Pazos S, Martinez-Pinna J, Castellano-Munoz M et al (2017) Molecular mechanisms involved in the non-monotonic effect of bisphenol-a on $\mathrm{Ca}^{2+}$ entry in mouse pancreatic $\beta$-cells. Sci Rep 7(1):11770. https://doi.org/10.1038/s41598-017-11995-3

24. Krege JH, Hodgin JB, Couse JF et al (1998) Generation and reproductive phenotypes of mice lacking estrogen receptor beta. Proc Natl Acad Sci U S A 95(26):15677-15682. https://doi.org/10. 1073/pnas.95.26.15677

25. Nadal A, Soria B (1997) Glucose metabolism regulates cytosolic $\mathrm{Ca}^{2+}$ in the pancreatic $\beta$-cell by three different mechanisms. Adv Exp Med Biol 426:235-243. https://doi.org/10.1007/978-1-4899$1819-233$

26. Valdeolmillos M, Nadal A, Contreras D, Soria B (1992) The relationship between glucose-induced $\mathrm{K}+\mathrm{ATP}$ channel closure and the rise in $[\mathrm{Ca} 2+] \mathrm{i}$ in single mouse pancreatic beta-cells. J Physiol 455(1):173-186. https://doi.org/10.1113/jphysiol.1992.sp019295

27. Huang da W, Sherman BT, Lempicki RA (2009) Systematic and integrative analysis of large gene lists using DAVID bioinformatics resources. Nat Protoc 4(1):44-57. https://doi.org/10.1038/nprot. 2008.211

28. Huang da W, Sherman BT, Lempicki RA (2009) Bioinformatics enrichment tools: paths toward the comprehensive functional analysis of large gene lists. Nucleic Acids Res 37(1):1-13. https://doi. org/10.1093/nar/gkn923

29. Livak KJ, Schmittgen TD (2001) Analysis of relative gene expression data using real-time quantitative PCR and the $2^{-\Delta \Delta \mathrm{C}_{\mathrm{t}}}$ method. Methods 25(4):402-408. https://doi.org/10.1006/meth.2001.1262

30. Zhang Q, Chibalina MV, Bengtsson $\mathrm{M}$ et al (2014) $\mathrm{Na}^{+}$current properties in islet alpha- and beta-cells reflect cell-specific Scn3a and Scn9a expression. J Physiol 592(21):4677-4696. https://doi. org/10.1113/jphysiol.2014.274209

31. Jacobson DA, Kuznetsov A, Lopez JP, Kash S, Ammala CE, Philipson LH (2007) Kv2.1 ablation alters glucose-induced islet electrical activity, enhancing insulin secretion. Cell Metab 6(3): 229-235. https://doi.org/10.1016/j.cmet.2007.07.010

32. Lee HS, Moon S, Yun JH et al (2014) Genome-wide copy number variation study reveals KCNIP1 as a modulator of insulin secretion. Genomics 104(2):113-120. https://doi.org/10.1016/j.ygeno.2014. 05.004

33. Hiriart M, Velasco M, Larque C, Diaz-Garcia CM (2014) Metabolic syndrome and ionic channels in pancreatic beta cells. Vitam Horm 95:87-114. https://doi.org/10.1016/B978-0-12-800174-5.00004-1

34. Kahn SE, Zraika S, Utzschneider KM, Hull RL (2009) The beta cell lesion in type 2 diabetes: there has to be a primary functional abnormality. Diabetologia 52(6):1003-1012. https://doi.org/10.1007/ s00125-009-1321-z

35. Moon MK, Jeong IK, Jung Oh T et al (2015) Long-term oral exposure to bisphenol A induces glucose intolerance and insulin resistance. J Endocrinol 226(1):35-42. https://doi.org/10.1530/JOE-140714

36. Nadal A, Alonso-Magdalena P, Soriano S, Quesada I, Ropero AB (2009) The pancreatic $\beta$-cell as a target of estrogens and xenoestrogens: implications for blood glucose homeostasis and diabetes. Mol Cell Endocrinol 304(1-2):63-68. https://doi.org/10. 1016/j.mce.2009.02.016

37. Hong SH, Sung YA, Hong YS et al (2017) Urinary bisphenol A is associated with insulin resistance and obesity in reproductive-aged women. Clin Endocrinol 86(4):506-512. https://doi.org/10.1111/ cen. 13270 
38. Lang IA, Galloway TS, Scarlett A et al (2008) Association of urinary bisphenol A concentration with medical disorders and laboratory abnormalities in adults. JAMA 300(11):1303-1310. https:// doi.org/10.1001/jama.300.11.1303

39. Wang T, Li M, Chen B et al (2012) Urinary bisphenol A (BPA) concentration associates with obesity and insulin resistance. J Clin Endocrinol Metab 97(2):E223-E227. https://doi.org/10.1210/jc. 2011-1989

40. Stahlhut RW, Myers JP, Taylor JA, Nadal A, Dyer JA, Vom Saal FS (2018) Experimental BPA exposure and glucose-stimulated insulin response in adult men and women. J Endocr Soc 2(10):1173-1187. https://doi.org/10.1210/js.2018-00151

41. EFSA (2015) Scientific opinion on bisphenol A. Available from http://www.efsa.europa.eu/sites/default/files/corporate_ publications/files/factsheetbpa150121.pdf. Accessed 15 Oct 2018

42. Jan LY, Jan YN (2012) Voltage-gated potassium channels and the diversity of electrical signalling. J Physiol 590(11):2591-2599. https://doi.org/10.1113/jphysiol.2011.224212

43. Jensen MV, Haldeman JM, Zhang H et al (2013) Control of voltage-gated potassium channel Kv2.2 expression by pyruvate- isocitrate cycling regulates glucose-stimulated insulin secretion. $\mathrm{J}$ Biol Chem 288(32):23128-23140. https://doi.org/10.1074/jbc. M113.491654

44. MacDonald PE, Sewing S, Wang J et al (2002) Inhibition of Kv2.1 voltage-dependent $\mathrm{K}^{+}$channels in pancreatic $\beta$-cells enhances glucose-dependent insulin secretion. J Biol Chem 277(47):4493844945. https://doi.org/10.1074/jbc.M205532200

45. Gore AC, Chappell VA, Fenton SE et al (2015) EDC-2: The Endocrine Society s second scientific statement on endocrinedisrupting chemicals. Endocr Rev 36(6):E1-E150. https://doi.org/ 10.1210/er.2015-1010

46. Gene Expression Omnibus (2019) In vivo effects of short-term treatment with Bisphenol A (BPA) on mice pancreatic islets. Available from https://www.ncbi.nlm.nih.gov/geo/query/acc.cgi? acc $=$ GSE126297. Accessed 10 Sept 2018

Publisher's note Springer Nature remains neutral with regard to jurisdictional claims in published maps and institutional affiliations. 